\title{
Exomorphic Characters of Seeds of Some Species of Capparaceae Family in Taif, KSA
}

\author{
Hatim M. Al-Yasi ${ }^{*}$ \\ ${ }^{1}$ Department of Biology, Faculty of Science, Taif University, Taif, Saudi Arabia.
}

Author's contribution

The sole author designed, analysed, interpreted and prepared the manuscript.

Article Information

DOI: 10.9734/ARRB/2019/v33i630136

Editor(s):

(1) Dr. Msafiri Yusuph Mkonda, Lecturer, Sokoine University of Agriculture, Tanzania.

Reviewers:

(1) Ugbabe, Grace E, National Institute for Pharmaceutical Research and Development (NIPRD), Nigeria.

(2) Musa, Saheed Ibrahim, University of Lagos, Nigeria.

(3) Dusit Athinuwat, Thammasat University, Thailand.

Complete Peer review History: http://www.sdiarticle4.com/review-history/52783

Original Research Article

Received 18 September 2019

Accepted 20 November 2019

Published 25 November 2019

\begin{abstract}
Seed exomorphic characters of six species belonging to four genera of family Capparaceae were studied using light microscope (LM) and scanning electron microscopy (SEM) in order to determine the importance of seed features as taxonomic evidence. These species are Cadaba farinosa Forssk, Capparis decidua (Forssk). Edgew, Capparis cartilaginea Decne, Dipterygium glaucum Decne, Maerua crassifolia Forssk and Maerua oblongifolia (Forssk.) A. Rich. The diagnostic characters at level of the general and specific level are shape of seed, size, color, texture and seed coat surface. There is a wide range of variations of seed shape among the studied species. LM revealed that the studied seeds are mostly varying from ovate to globose or cardiac- shape. All of the seeds lack wings except Dipterygium glaucum Decne. and most of the seed is coarse texture. There are six main types of seed surface sculptures revealed by SEM investigation at higher magnifications; reticulate, rugose-striate, winding undulate, ribbed and papillate.
\end{abstract}

Keywords: Capparaceae; seed coat sculpture; LM; SEM; Saudi Arabia.

\section{INTRODUCTION}

Capparaceae is a family that has $40-45$ genera and $700-900$ species or more because of this, it is considered as a medium-sized family and it has a few members as horticultural or economic importance. It is pan tropical in distribution. The family inhabits the warmer parts of the world, 
mainly in the tropics and subtropics of both hemispheres and in the Mediterranean. It appears in flora of dry regions. After updating some families, Capparaceae became represented in the wild Saudi Arabia flora by 4 genera, 10 species of wide ecological and biogeographically range of distribution [1], 6 species belonging to 4 genera [2] and 8 species belonging to 5 genera [3]. Capparaceae that includes Morisonia, Crataeva, Cadaba, Boscia, and other New World and Old-World genera [4]. The different genera overlap in molecular studies [4], although they have a marked biogeographical distinction between New World and Old-World groups, recognized at the section level or subsection $[4,5,6]$. It is important to ultra-structural shape analysis of the seed surface showed in the SEM as a credible approach for distinguishing the tax a and assess taxonomic characteristics, as seen in works of Barthlott, $[7,8,9]$. The morphology of the seed surface sculpture in the SEM for this family so far. The purpose of the present work is to determine exomorphic studies of some seeds of Capparaceae family by using
LM and SEM to ascertain the structure of the seed surface considered as a taxonomic figure.

\section{MATERIALS AND METHODS}

Seeds collection: Mature seeds were collected from the natural habitat at different localities at Taif province (Table 1). The locations were accurately located using GPS. (Fig. 1). The external macro-morphological aspect of the seeds including seed size, general shape, seed surface, color, were investigated with the aid of light microscope (LM) and scanning electron microscope (SEM). The external macromorphological features of the seeds in the studied species were investigated with the aid of scanning electron microscope (SEM). Dried mature seeds were mounted on brass stubs and coated by with a thin layer of gold. Coated seeds were examined and photographed on a Joel JSM 6390LA, at the Electronical Microscope Unit in University of Taif. The terminology of Barthlott [7] and Stearn [10] were adopted to describe the SEM of seed surface.

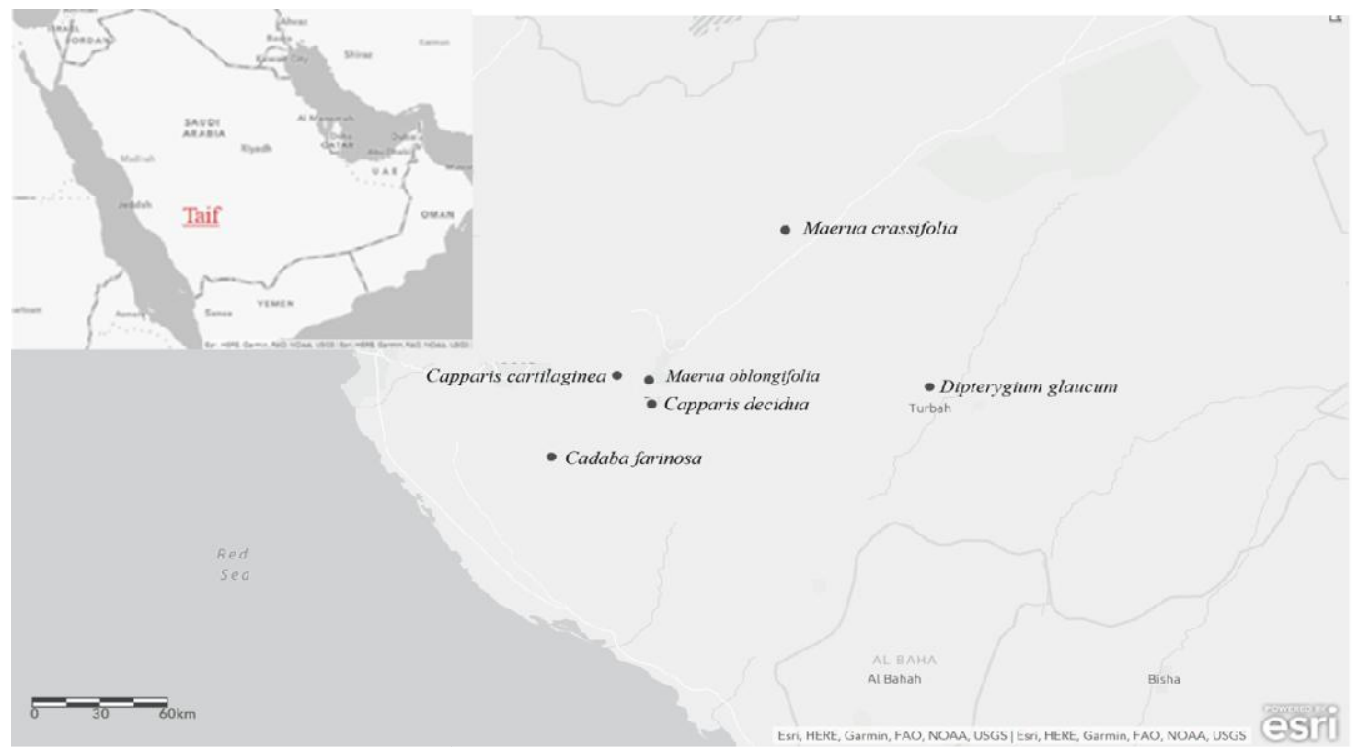

Fig. 1. Location map of the study area showing the different species at Taif Region

Table 1. Coordinates of sampled locations in the study area

\begin{tabular}{|c|c|c|c|c|}
\hline Species name & Location & Latitude (N) & Longitude (E) & Altitude (m) \\
\hline Cadaba farinosa Forssk & Taif - alhada & $21^{\circ} 20^{\prime} 26.3$ & $40^{\circ} 15^{\prime} 26.5$ & 1370 \\
\hline Capparis decidua (Forssk.) Edgew & Taif - Makkah road & $21^{\circ} 19^{\prime} 54.3$ & $40^{\circ} 25^{\prime} 09.9$ & 1545 \\
\hline Capparis cartilaginea Decne & Taif - alhada & $21^{\circ} 20^{\prime} 58.7$ & $40^{\circ} 17^{\prime} 32.5$ & 2058 \\
\hline Dipterygium glaucum Decne & Taif - alkhorma & $22 \circ 10^{\prime} 35.4$ & $41^{\circ} 36^{\prime} 53.5$ & 1026 \\
\hline Maerua crassifolia Forssk & Taif - Riyadh road & $21^{\circ} 36^{\prime} 21.1$ & $40^{\circ} 40^{\prime} 58.6$ & 1320 \\
\hline Maerua oblongifolia (Forssk.) A. Rich & Taif & $21^{\circ} 13^{\prime} 58.2$ & $40^{\circ} 25^{\prime} 39.4$ & 1696 \\
\hline
\end{tabular}




\section{RESULTS AND DISCUSSION}

A wide range of variations of the seed shape has been shown among the species. Most of the seeds differ from ovate to cardiac-shape or globose. Nevertheless, they are ovate in the three species (Capparis cartilaginea, Dipterygium glaucum and Maerua oblongifolia (Forssk.), two species cardic-shape Capparis decidua and Maerua crassifolia were cadic-shaped while Cadaba farinosa was globose. (Figs. 8 \& 9). In this study we notice the seed shape appear as a diagnostic at the general level. There is no occurrence of wings in most of the seeds investigated. However, in Dipterygium glaucum the presence or absence of wings has a diagnostic value in distinguishing the studied species. Our data have shown significant propinquity with previous works of Kapil, et al. [11], Abdel Khalik, et al. [12], Tantawy, et al. [13] and Kasem, et al. [14].

As shown in Table 2, Seed size in this study is divided into two sizes. The small size is in the range of L: $0.3, \mathrm{~W}: 0.3 \mathrm{~mm}$ as Cadaba farinosa $(0.3 \times 0.1)$, Capparis decidua $(0.3 \times 0.3)$ and Capparis cartilaginea $(0.3 \times 0.2)$. While the big size in the range of ( $\mathrm{L}: 0.5, \mathrm{~W}: 0.2 \mathrm{~mm})$ as Dipterygium glaucum Decne $(0.5 \times 0.3)$, Maerua crassifolia $(0.5 \times 0.3)$ and Maerua oblongifolia $(0.5 \times 0.2)$. Seed size is considered a diagnostic variable to a certain extent (Table 2). This is agreeing with the study of Tantawy, et al. [13] and Aniszewski, et al. [15].

The light microscope (LM) showed the color of seeds ranging from white, brown and dark brown to brown (Table 2 and Fig. 8.). The color of the seed is diagnostic at the generic and specific level to a certain degree. This is in corroboration with the works of Dahlgren and Clifford [16] and Barthlott [7]. Five species had coarse seeds
(Capparis decidua, C. cartilaginea, Diplerygium glaucum, Maerua crassifolia and M. olongifolia) while only one species (Cadaba farinosa) had glabrous textured seed.

SEM examination showed 6 types of seed sculpture; reticulate, winding, rugose, undulate, papillate and ribbed. The reticulate seed surface pattern in Capparis cartilaginea, winding type was recorded in Capparis decidua rugose-striate form was noticed in Cadaba farinosa undulate structure was found in Dipterygium glaucum and ribbed structure was in Maerua crassifolia and papillate seed surface in Maerua oblongifolia. It was observed from the SEM result; surface sculpture of the seed, sides of the anticlinal and periclinal walls can be considered as diagnostic parameters at the general and specific level in this study. That is compatible with the study of Barthlott [7,17] Fayed and El-Naggar [18] and Abdel Khalik and Maesen [12] and Tantawey, et al. [14].

Cadaba farinosa Forssk: Seeds are small, shape globose, thick, black color, Size : $0.3 \times 0.1$ $\mathrm{mm}$, seed wing absent, SEM showed rugose striate sculpture on their seed coat (Fig. 2) seeds are large, Cardiac-shape, thick, black color, globrous surface.

Capparis decidua (Forssk.) Edgew: Seed size: $0.3 \times 0.3 \mathrm{~mm}$, seed wing absent, seed surface ornamentation revealed irregular ornamentation, randomly patterned surface with winding cells prominently shown (Fig. 3).

Capparis cartilaginea Decne: Seeds are relatively large, light brown color, thick, seed size: $0.3 \times 0.2 \mathrm{~mm}$ seed wing absent, both the dorsal and ventral sides are ornamented with minute tubercles in regular rows. The surface in these places appears reticulately sunken (Fig. 4).
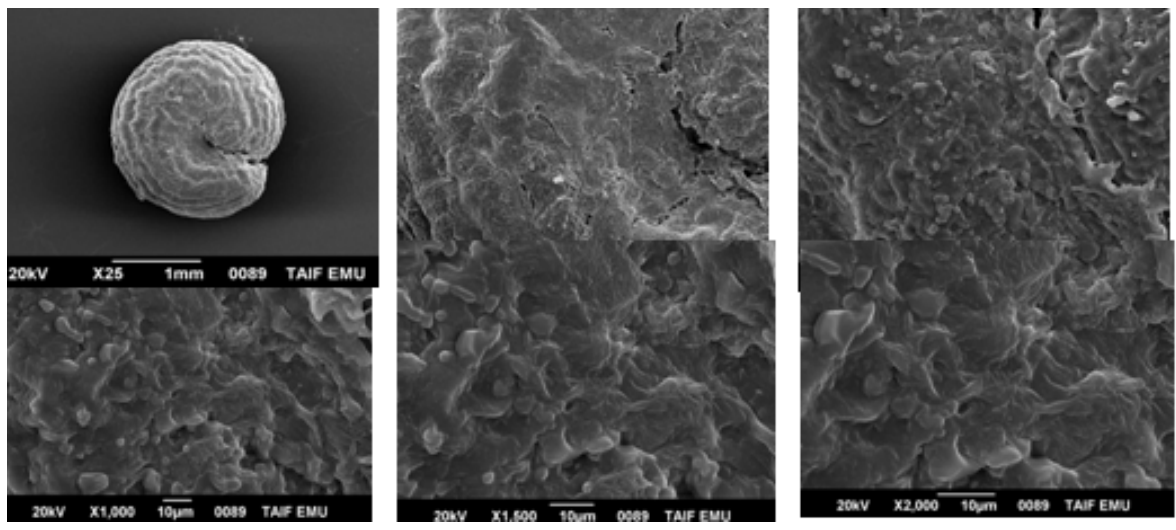

Fig. 2. SEM of Cadaba farinosa seed 

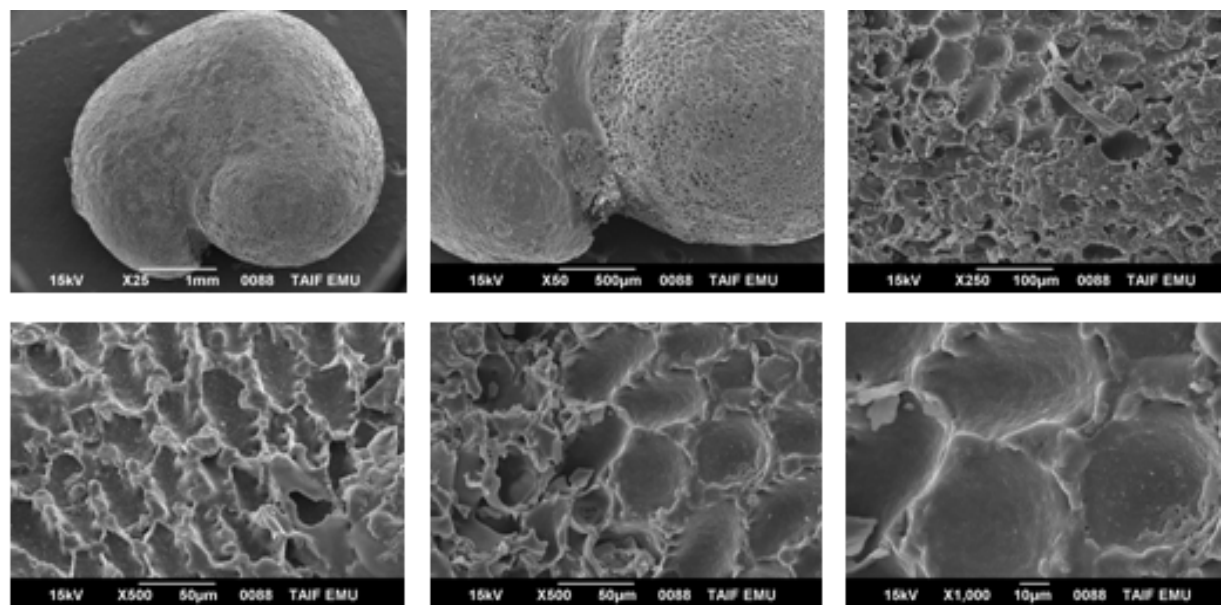

Fig. 3. SEM of Capparis decidua seed
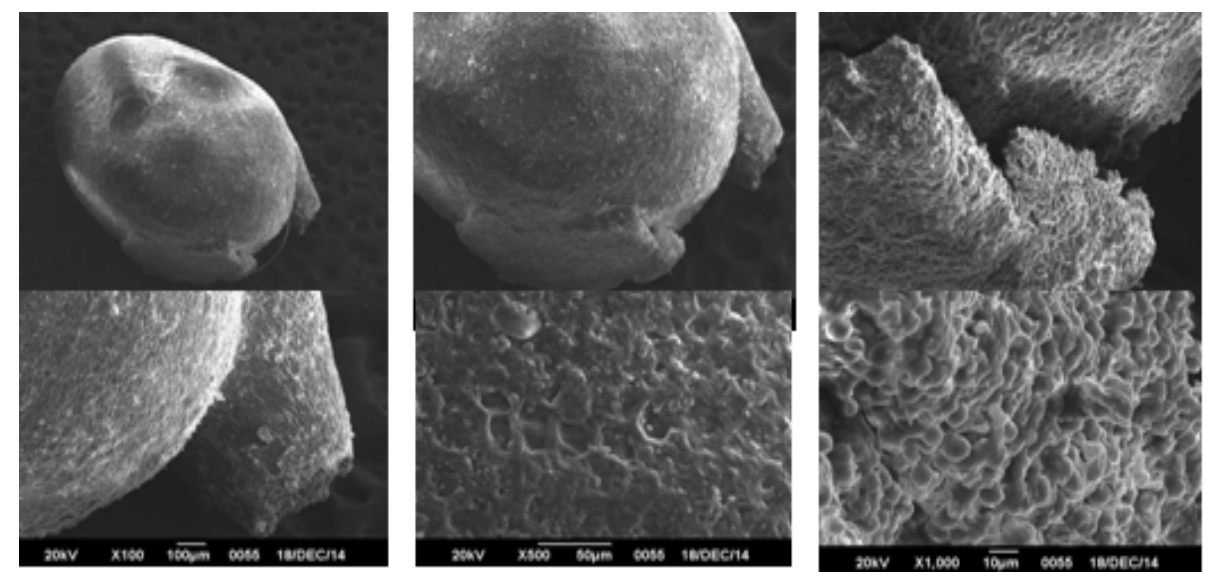

Fig. 4. SEM of Capparis cartilaginea seed
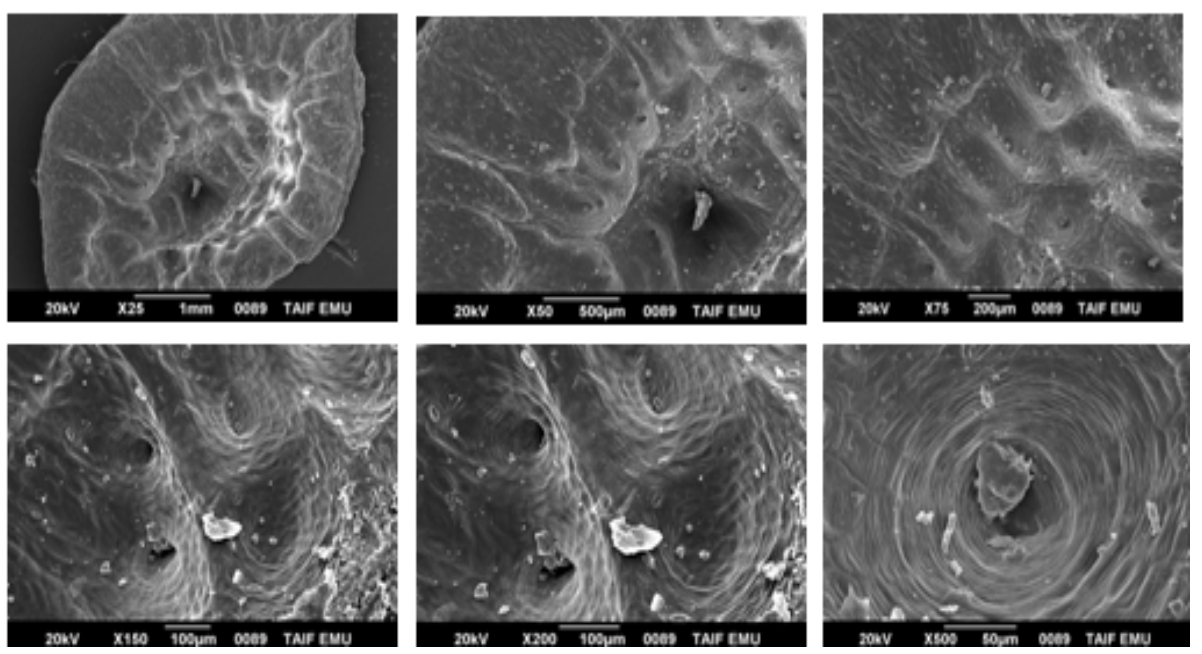

Fig. 5. SEM of Dipterygium glaucum seed 

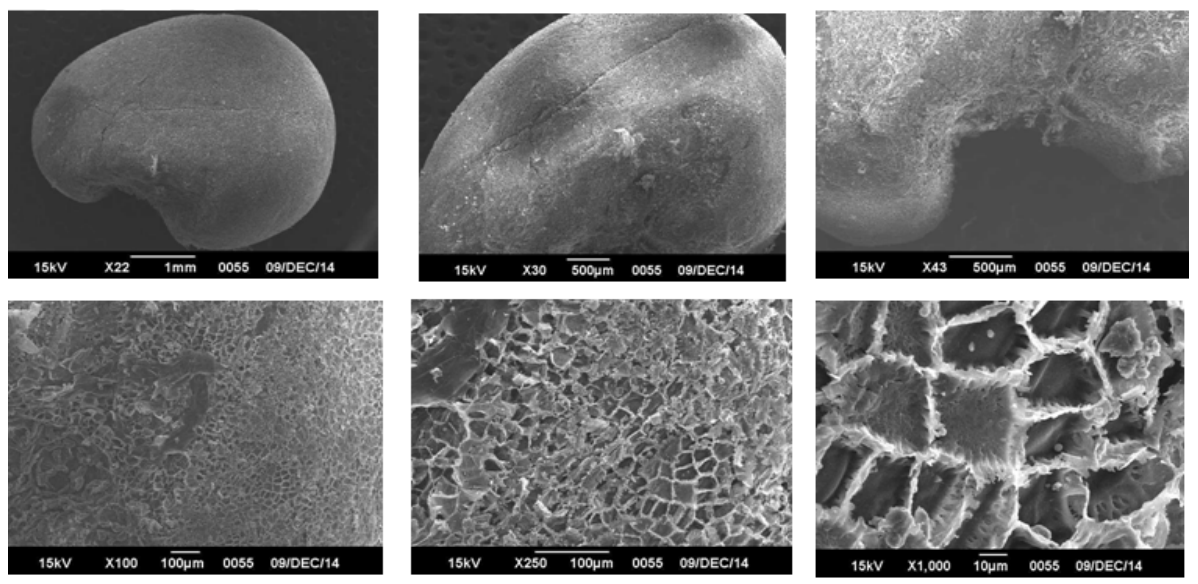

Fig. 6. SEM of Maerua crassifolia seed
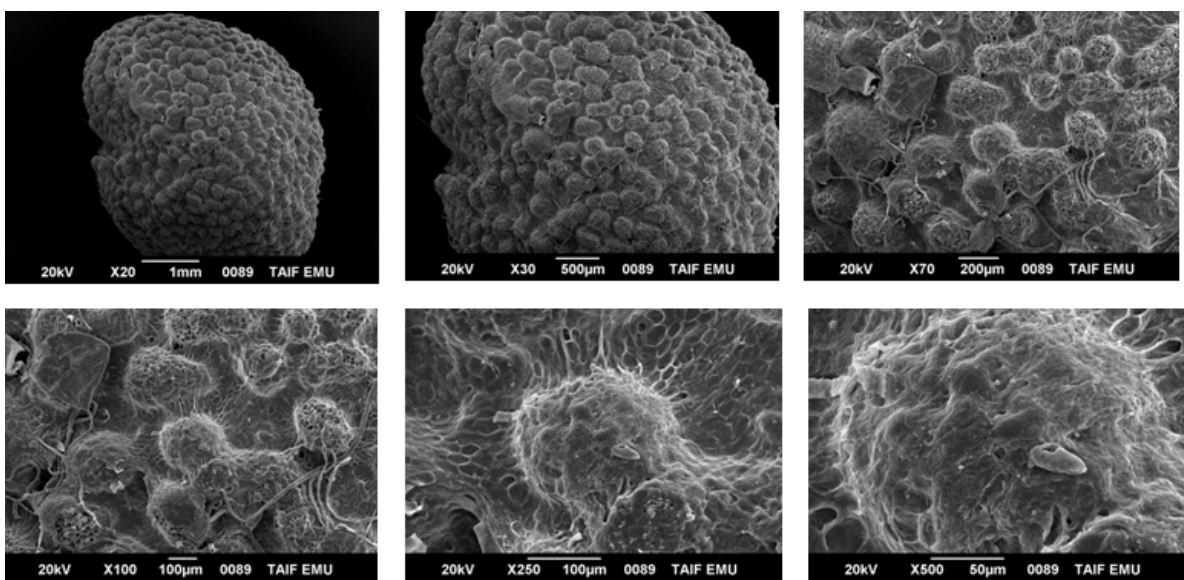

Fig. 7. SEM of oblongifolia seed

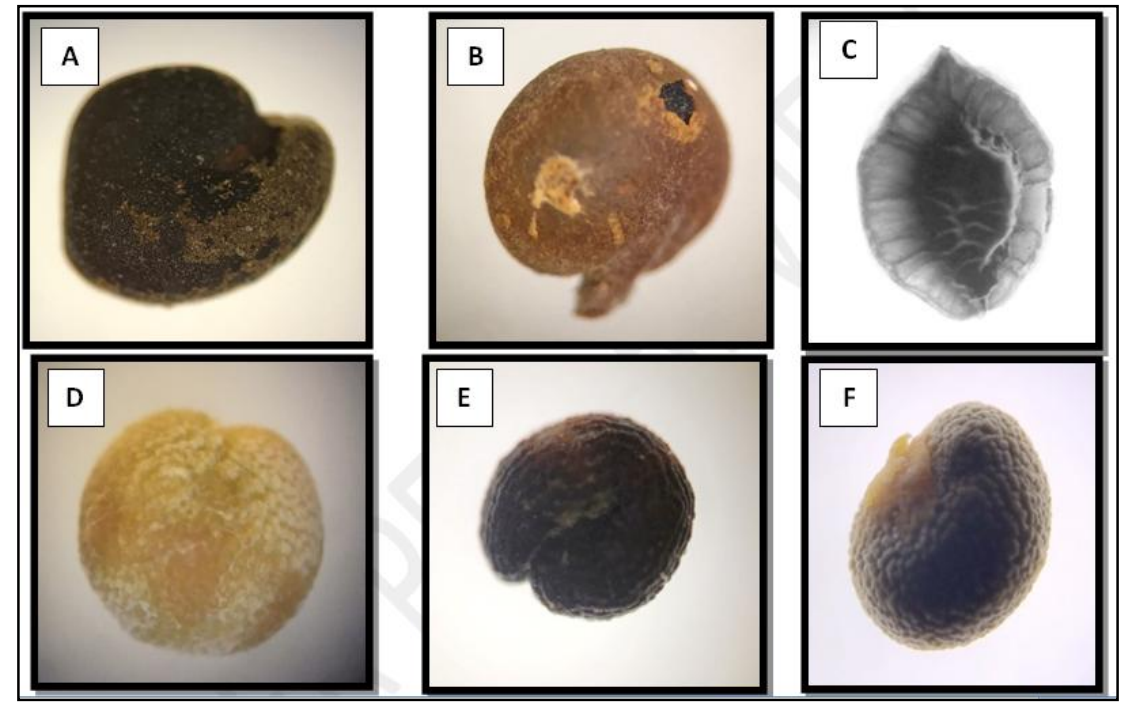

Fig. 8. General view of seeds in light microscope. A; Capparis decidua , B; Capparis cartilaginea , C; Dipterygium gloncum , D; Maerua crssifolia, E; Cadapa farinosa F; Maerua oblongifolia 


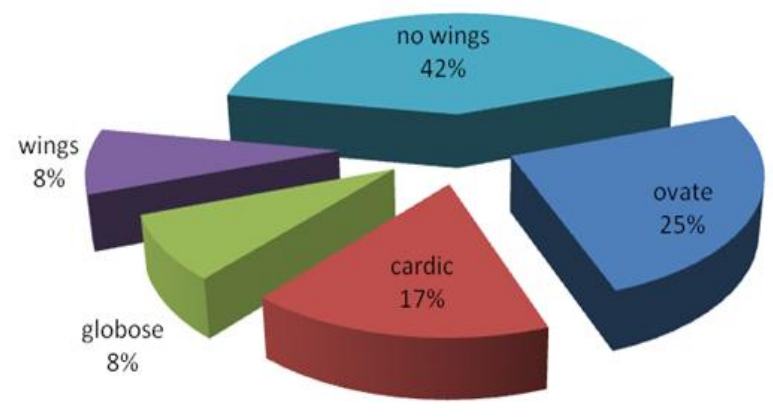

Fig. 9. Percentage Seeds shape spectra of the studied species.

Table 2. Seed morphological characters as seen by (LM) and (SEM)

\begin{tabular}{|c|c|c|c|c|c|c|}
\hline Species name & $\mathbf{L x}_{\mathrm{x}} \mathbf{W}$ & Shape & Texture & Color & Wing & Seed surface \\
\hline Cadaba farinosa Forssk & $0.3 \times 0.1$ & globose & Coarse & Black & Absent & rugose-striate \\
\hline Capparis decidua (Forssk.) Edgew & $0.3 \times 0.3$ & cardic & Coarse & Black & Absent & winding \\
\hline Capparis cartilaginea Decne & $0.3 \times 0.2$ & Ovate & Coarse & Darck-brown & Absent & reticulate \\
\hline Dipterygium glaucum Decne & $0.5 \times 0.3$ & $\begin{array}{l}\text { ovate } \\
\text { oblong }\end{array}$ & Coarse & Brown & Present & Undulate \\
\hline Maerua crassifolia Forssk & $0.5 \times 0.3$ & Cardic & Glabrous & White & Absent & ribbed \\
\hline Maerua oblongifolia (Forssk.) A. Rich & $0.5 \times 0.2$ & Ovate & Coarse & Brown & Absent & Papillate \\
\hline
\end{tabular}

Dipterygium glaucum Decne: Seeds are large, shape ovate-oblong, seed Size: $0.5 \times 0.3 \mathrm{~mm}$, brown color wing present. SEM revealed undulate with globular pieces perfectly deep in the cells of epidermal and interlaced shapes were registered on the surface (Fig. 5).

Maerua crassifolia Forssk: Seeds are large, Cardiac-shape, thick, white color, smooth surface. Size of seed: $0.5 \times 0.3 \mathrm{~mm}$, seed wing not present, seed surface ornamentation revealed the anticlinal walls are conformable and appeared arrange ornamentation, randomly patterned surface with ribbed cells prominently shown (Fig. 6).

Maerua oblongifolia (Forssk) A. Rich: Seeds are large, thick, and ovate in shape, brown color, Size $0.5 \times 0.2 \mathrm{~mm}$, seed wing absent, the surface of lobular appears with globular central papillae. (Fig. 7).

\section{CONCLUSION}

There is a wide range of variations of seed shape among the studied species. LM revealed that the studied seeds are mostly varying from ovate to globose or cardiac- shape. All the seeds lack wings except Dipterygium glaucum Decne. and most of the seed is coarse texture. There are six main types of seed surface sculptures revealed by SEM investigation at higher magnifications; reticulate, rugose-striate, winding undulate, ribbed and papillate.

\section{COMPETING INTERESTS}

Author has declared that no competing interests exist.

\section{REFERENCES}

1. Collenette S. Wildflowers of Saudi Arabia. NCWCD (National commission for Wildlife Conservation and Development, Publication), Saudi Arabia. 1999;799.

2. Chaudhary S, Al-Jowaid A. Flora of the Kingdom of Saudi Arabia. Second printing, National Agriculture \& Animal Resources Research Center, K.S.A. Riyadh; 2013.

3. Al Sroor AS. Illustrated Atlas of Wild Plants. In Arabia. 2019;827. ISBN: 978-603-02-8308-8

4. Hall JC, Sytsma KJ, Iltis HH. Phylogeny of Capparaceae and Brassicaceae based on chloroplast sequence data. American Journal of Botany. 2002;89:1826-1842. 
5. Bentham G, Hooker JD. Genera plantarum, Vol. I. Reeve, London; 1862.

6. Candolle AP De. Capparis. in Prodromus systematis naturalis regni vegetabilis, Vol. 1. Treuttel et Wu "rtz, Paris.1824;245-54.

7. Barthlott W. Epidermal and seed surface characters of plants: Systematic applicability and some evolutionary aspects. Nordic J. Bot. 1981;1:345-355.

8. Koul KK, Nagpal R, Raina SN. Seed coat microsculpturing in Brassica and Allied genera (Subtribes Brassicae, Raphaninae, Morcandinae). Annals of Botany. 2000;86: 385-397.

9. Gamarra R, Dorda E, Scrugli A, Galán P and Ortúñez E. Seed micromorphology in the genus Neotinea Rchb. f. (Orchidaceae, Orchidinae). Botanical Journal of the Linnean Society. 2007;153:133-140.

10. Stearn TW. Botanical Latin, 3rd edition. David \& Charles. Britain; 1983.

11. Kapil RN, Bor J, Bouman F. Seed appendages in Angiosperms. I. Introduction. Bot. Jahrb. Syst. 1980;101: 555-73.

12. Abdel Khalik K, Maesn V. Seed morphology of some tribes of Brassicaceae (Implication for taxonomy and species identification for the flora of Egypt). Blumea. 2002;47:363-83.

13. Tantawy M, Sayed F, Soad A, Ghalia T. Seed exomorphic characters of some Brassicaceae (LM and SEM Study). International J. of Agriculture and Biology. 2004;1560:821-830.

14. Kasem WT, Ghareeb A, Marwa E. Seed morphology and seed coat sculpturing of 32 Taxa of Family Brassicaceae. Journal of American Science. 2011;7(2).

15. Aniszewski T, Mervi K, Leinonen A. Seed number, seed size and seed diversity in Washington Lupin (Lupinus polyphyllus Lindl). Ann. Bot. 2001;87:77-82.

16. Dahlgren RM, Clifford HT. The monocotyledons. Academic Press, London;1982.

17. Barthlott W. Microstructural features of seed surfaces. In: Heywood, V.H., Moore, D.M. (Eds.), Current Concepts in Plant Taxonomy. Academic Press, London. 1984;95-105.

18. Fayed AA, El-Naggar SM. Taxonomic studies on Cruciferae in Egypt. 4. Seed morphology and taxonomy of the Egyptian species of Lepidieae. Bull. Fac Sci Assiut Univ. 1996;25:43-50.

(c) 2019 Al-Yasi; This is an Open Access article distributed under the terms of the Creative Commons Attribution License (http://creativecommons.org/licenses/by/4.0), which permits unrestricted use, distribution, and reproduction in any medium, provided the original work is properly cited.

Peer-review history:

The peer review history for this paper can be accessed here: http://www.sdiarticle4.com/review-history/52783 